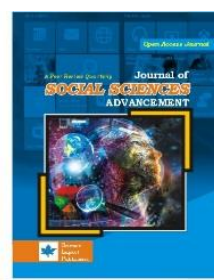

Available Online

Journal of

Social Sciences Alotoancement

www.scienceimpactpub.com/jssa

\title{
Exploring the Factors that affect Education Branding and Image Creation in B-School: Using Factor Analysis
}

\author{
Manoj Kumar Mishra1*, Priyanka Singh² and Nidhi Shrama1 \\ ${ }^{1}$ Rukmini Devi institute of Advanced Studies, Delhi, India \\ 2Pranveer Singh Institute of Technology, Kanpur-UP, India
}

\begin{abstract}
Over the last decade, business education has been a popular topic of study for those pursuing higher education. Because the IIMs/IITs and top B-schools are unable to meet this demand, private firms have been allowed to enter the market. This has resulted in severe competition among B-schools, and the education business has never been more competitive. Due to the intense competition among B-Schools (especially private institutions/universities), they have decided to trademark their education. This research is being carried out with the primary goal of determining the most influential aspects in the development of the business school as a brand from the student's perspective. A structured questionnaire was used to elicit responses from respondents about the concept of educational branding. The statistical tool of factorial analysis is used to study the factors of educational branding. The exhibits of Educational Brand image construction model by private institutions and the articulation seen by future managers are explored in this study. This also allows institutions to place a greater emphasis on elements that have a high ranking among students rather of examining all of them.
\end{abstract}

\footnotetext{
Keywords: $\quad$ Educational branding, Factorial analysis, Image creation model

*Corresponding Author: Manoj Kumar Mishra, Email: misramanoj22@gmail.com

(C) The Author(s) 2021.
}

\section{INTRODUCTION}

The world's largest population of about 500 million people between the ages of 6 and 23.India has a literacy rate of only $73 \%$, compared to the world average of $84 \%$, providing an opportunity for private stakeholders to explore untapped markets Katiyar (2016). Due to increased liberalization, privatization, and globalization, India's objectives to develop a knowledge society are based on the notion that higher education essentially empowers people with the necessary competitive skills and information Paniker (2020). For this reason, higher education is also increasingly focused on quality and excellence. Given the size and growth of India's education sector, many private sector education institutions / universities have developed throughout the country Panikkar \& Nair (2012). Figure 1 gives an understanding about the increasing share of state private universities.

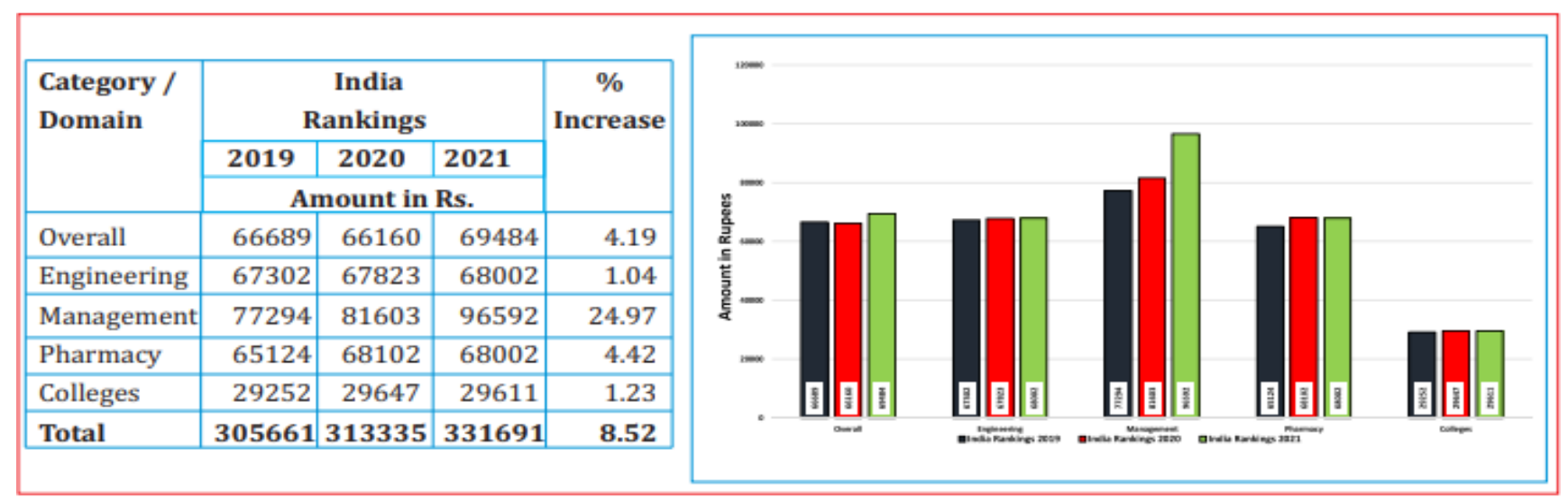

Figure: 1 NIRF report-2021

In 2020, the Indian school market is worth $\$ 34.3$ billion. The market is expected to increase at a CAGR of 13.74 percent between 2021 and 2026, according to IMARC Group. We're constantly watching and evaluating the pandemic's direct and indirect effects, keeping in mind the uncertainty of COVID-19. As a prominent market contributor, these insights are incorporated in the research. Figure 2 represents the potential of higher education in future. 

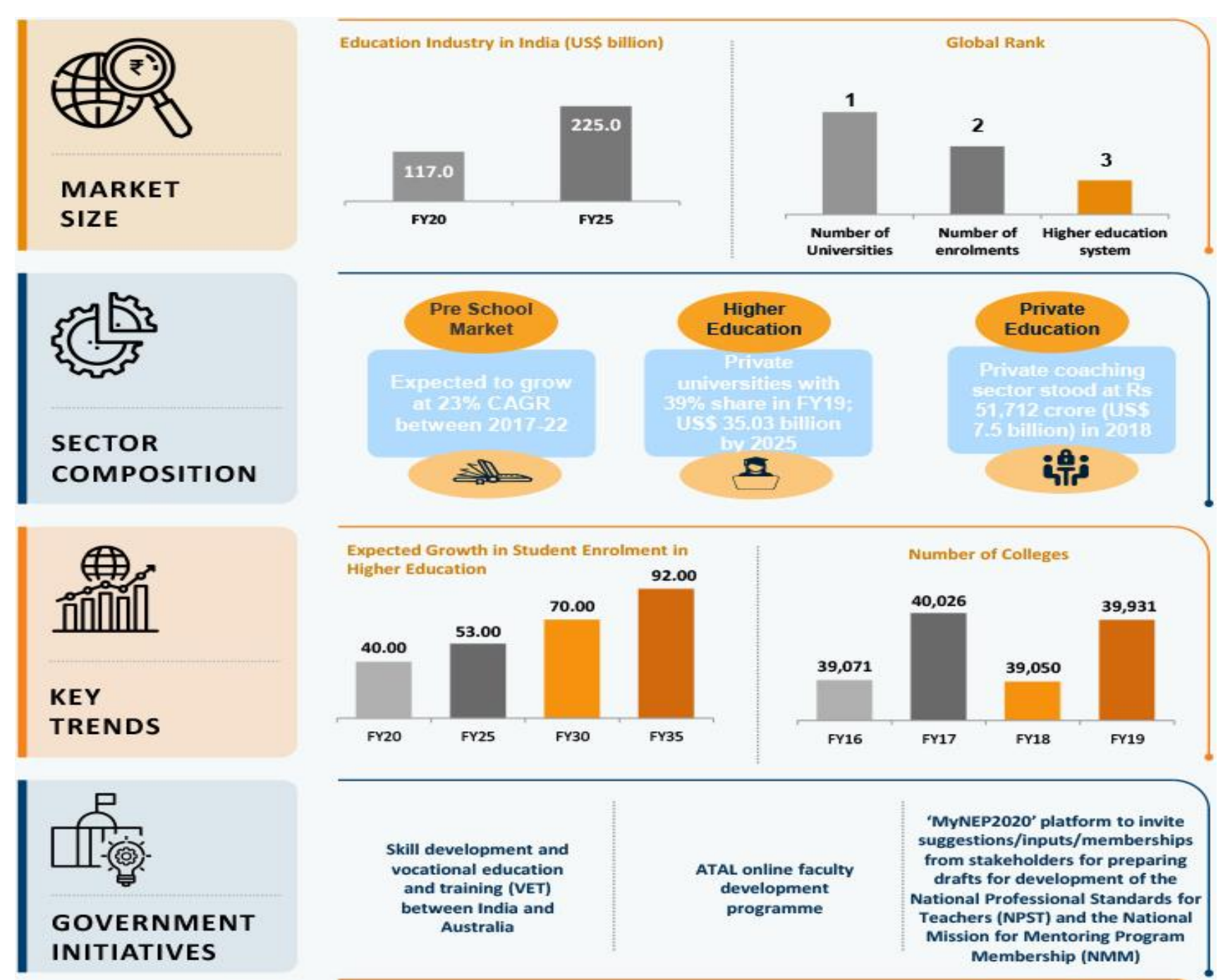

Figure 2: source; https://www.ibef.org/industry/education-sector-india/infographic

According to Hemsley-Brown et al., (2016) the notion of Educational Branding in higher education was born out of the marketplace, competitive environment, globalization, and integration. . As a result, today's edupreneurs are taking every conceivable step to establish a brand name for their institute/university Jayaraman \& Praseed. "Educational" term is elucidated as the process of facilitating learning, acquiring knowledge for the development of the skills, values, beliefs of any environment or as a whole. Today the educational institutes are focusing on commercialization of their institute by crating the brand of their institutions in their mind for their perspective consumes- Students. Gupta, Manish, Singh, P.B quotes "On account of global trends towards privatization of education, there is an increased competition be it haloed IIMs or ISB, S P Jain, MICA or IMT or international institutions like Harvard, Stanford, Princeton Yale" etc.

"93 percent of administrators in higher education already considered their school to be a brand," according to a recent survey by marketing firm Noir sur Blanc. Institutions are putting significantly more emphasis on branding and marketing than in past years. Many have employed corporate marketing consultants and spent substantial time and money to develop powerful institutional brands.

\section{Evolution of B-school Education:}

In India, B-School education has a lengthy history stretching back to the nineteenth century. Early B-Schools were primarily concerned with the commercial aspect of business, aiming to meet the needs of the British government at the time.

- Commercial School of Pacchiappa Charties, India's first business school, was founded in Chennai in 1886. (Madras). In 1903, the British government established secondary school level commerce programs at Calcutta's Presidency College, focusing on secretarial practice, business communication, shorthand, typing, correspondence, and accounting.

- Sydenham College, Mumbai's first college-level business school, was established in 1913. In 1920, another college in Delhi was established as Commerce College, which was eventually called Sri Rama College of Commerce. 
- The Indian Institute of Social Science was established in 1948 as India's first management program with the goal of training workers to develop and disseminate the information needed to run industrial firms in India. In 1949, the Catholic community established the Xavier Labor Relations Institute (XLRI) in Jamshedpur.

- Calcutta's Indian Institute of Social Welfare \& Business Management (IISWBM) was founded in 1953. That was the first formal Management Institute in India. In 1961, the Government of India asked for and received funding from the Ford Foundation to establish two (2) Indian Institutes of Management, one in Calcutta (West Bengal) and the other in Ahmadabad (Gujarat). This funding was intended to aid in the transfer of American business education knowledge and models to other countries, as well as to foster close partnership with American BSchools to facilitate learning transfer.

- During the 1990s, there was an increase in both numbers and status. India has attracted a considerable number of global corporations. In order to compete with global firms, domestic enterprises followed suit. Companies discovered that graduates from the commerce stream fell well short of the requirements of executive jobs in today's competitive market. They were good accountants, but they lacked the necessary marketing, behavioral, financial, and operations abilities. Oral and written communication, critical thinking and critical reading abilities, and information technology were also lacking. As a result, rather than spending training costs for commerce graduates, corporations began offering massive bonuses to MBA grads. Universities began to look at management education as an academic field and began providing MBA and BBA degrees in response to the popularity of MBA programs and requests from students and employers.

\section{BRANDING EDUCATIONAL INSTITUTIONS}

Education branding (particularly universities and professional institutions) is still in the early stages of differentiation based on self-defined sets of features and attributes.

a. In some circumstances, there is a historical accident of famous history that distinguishes unique university "brands" based on a well-known reputation.

b. To create value among customers, every educational institution must aim to construct their own branding foundation. They accomplish this by utilizing the functions listed below.

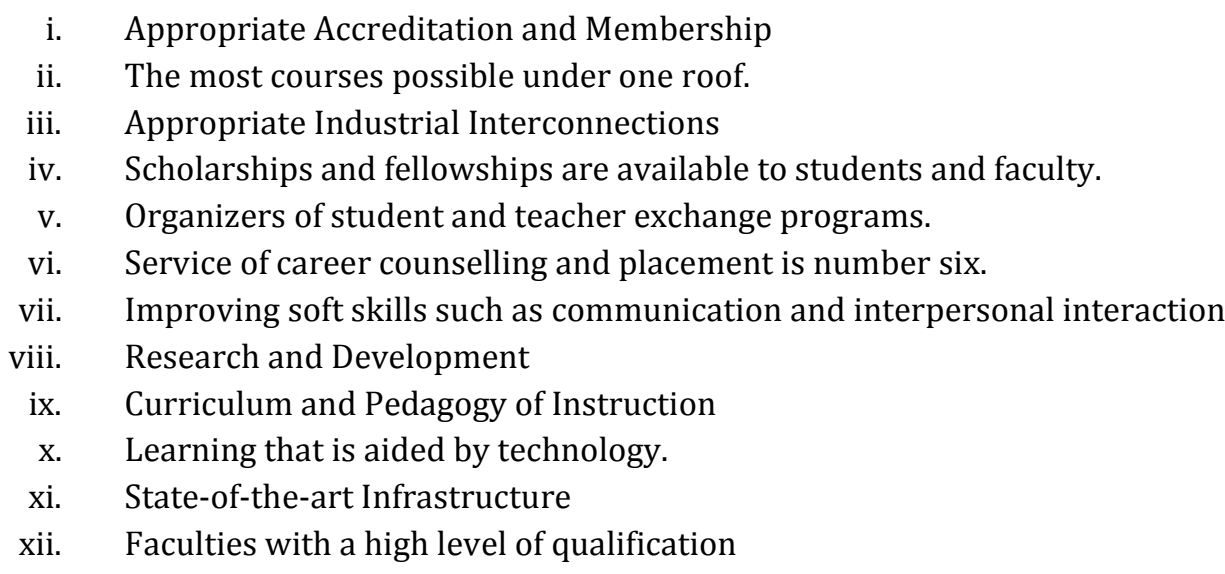

\section{LITERATURE REVIEW}

Colleges and universities have begun to embrace the fundamentals of integrated marketing and branding Retamosa et.al. (2020,), such as the sum total of all associations made with an organization or product, and the use of "Branding," which involves concerted efforts to influence desired brand associations; the process that moves an organization from the existing brand to the desired brand, according to Paul Herr (1996) Boix, et.al, (2020).

However, the authors find evidence to support their claim that a university's brand image has a significant impact on public perceptions of that institution and the sector as a whole (Yavas and Shemwell, 1996; Landrum et al., 1998). According to a study on university image (Paramewaran and Glowacka, 1995), higher education institutions must retain or generate a distinct image in order to gain a competitive edge in a market that is becoming increasingly competitive.

Unsurprisingly, some academics oppose these recommendations, claiming that "branding is anathema to higher education: it suggests central control and consistency, whereas universities must be about freedom and activity." In business, branding is about bringing personality to places where it doesn't already exist, but there's almost too much personality in colleges" (Roberts cited by Lewis, 2003). 
The majority of the time, positioning entails developing unique traits and features of the product or service being supplied. In his article, Anthony Lowrie (2007) investigates how brand identity emerges during periods of articulation. With the increased emphasis on vocational relevance in higher education, governmental discourses and university marketing activities have given rise to an unfavorable university identity. Empirical data from a three-anda-half-year ethnographic study shows how marketing language appeals to a wide range of consumers and how this activity relates to higher education policy.

The image of colleges is another aspect that influences their brand values. Students may prefer universities because of their image (Iqbal et al., 2012). To set themselves apart from their competition, every university requires a favorable image and a brand through which to project that image (Parameswaran and Glowacka, 1995). In terms of prospective students' preference for institutions, a university's image can be more beneficial than the quality of its instruction (Mazzarol, 1998). The image of a university is a phenomenon that is intimately linked to the name of that university. In fact, a university's name is known to conjure up images and memories (Bulotaite, 2003). Choosing names with care is the first step in establishing a positive image for universities. Universities with catchy, attentiongetting names that have positive connotations can maintain a positive image and increase brand value in higher education.

\section{METHODOLOGY FOR RESEARCH}

\section{Design of questionnaire}

In this study, the qualitative approach was employed as the theories uses for the research are well developed. The instrument was a structured questionnaire, which was distributed to respondent from two cities of UP (East), Kanpur and Bareilly. Three B-schools from each cities are selected for sampling.

\section{Sampling}

The samples were collected using stratified convenience sampling. The major attribute of the strata was the academic background of the respondent. Total 180 students were surveyed from 6 different colleges. Only 150 students were responded and returned the filled questionnaires. Out of that only 120 were in a usable condition, rest were consisting the incomplete information.

The respondent are the UG level students and they were asked to respond on the 5-scale factor for the 20 factors of education service quality which used for education branding.

\section{RESULT OF FACTOR ANALYSIS}

To quantify and examine whether the constructs in this study were appropriate for factor analysis, researchers used Kaiser-Meyer-Olkin (KMO) sampling adequacy and Bartlett's test of sphericity. Factor analysis can be performed if the KMO sampling adequacy value is more than 0.6 and the p-value of the Bartlett test of sphericity is near to 0.

Table 1: KMO and Bartlett's Test

\begin{tabular}{llr}
\hline \multicolumn{2}{l}{ Kaiser-Meyer-Olkin Measure of Sampling Adequacy. } & .642 \\
\hline \multirow{3}{*}{ Bartlett's Test of Sphericity } & Approx. Chi-Square & 573.708 \\
& Df & 190 \\
& Sig. & .000 \\
\hline Based on correlations & &
\end{tabular}

The Kaiser-Meyer-Olkin measure of sampling adequacy is computed to test the sampling adequacy, and it is determined to be 0.642 . The sample has been determined to be suitable for sampling.

The overall significance of the correlation matrix is examined using the Bartlett sphericity test for educational branding components (approx. chi square $=573.708$ significant at 0.000 ), as well as support for the validity of the data set's factor analysis.

As a result, all of these criteria suggest that the data is eligible for factor analysis. We used principal components analysis and the latent root criterion to extract factors. Methods of rotation, such as orthogonal rotation with Varimax, were also used. Only components with latent roots or Eigen values larger than 1 meet the latent root requirement.

\section{Factors affecting B-schools Branding}

By using Extraction method (Principal Component Analysis) 20 factors of B-School branding are extracted into 8 factors which give major impact on B-school branding. The current solution's index is responsible for 70.044 percent of the overall variations in B-school Branding. Because we can reduce the number of option elements, it's a pretty good extraction. (In other words, from 20 statements to 8 underlying factors) Factor one accounts for $20 \%$ of 
variation, whereas factors $2,3,4,5,6,7$, and 8 account for $9.675 \%, 8.477 \%, 7.641 \% 6.935 \%, 6.116 \%, 5.964 \%$, and $5.236 \%$, respectively.

Table 2: Total Variance Explained

\begin{tabular}{|c|c|c|c|c|c|c|c|c|c|}
\hline \multirow[t]{2}{*}{ Component } & \multicolumn{3}{|c|}{ Initial Eigen values } & \multicolumn{3}{|c|}{ Extraction Sums of Squared Loadings } & \multicolumn{3}{|c|}{ Rotation Sums of Squared Loadings } \\
\hline & Total & $\%$ of Variance & Cumulative \% & Total & $\%$ of Variance & Cumulative \% & Total & $\%$ of Variance & Cumulative $\%$ \\
\hline 1 & 4.000 & 20.000 & 20.000 & 4.000 & 20.000 & 20.000 & 2.748 & 13.740 & 13.740 \\
\hline 2 & 1.935 & 9.675 & 29.675 & 1.935 & 9.675 & 29.675 & 1.888 & 9.442 & 23.182 \\
\hline 3 & 1.695 & 8.477 & 38.152 & 1.695 & 8.477 & 38.152 & 1.725 & 8.626 & 31.808 \\
\hline 4 & 1.528 & 7.641 & 45.793 & 1.528 & 7.641 & 45.793 & 1.635 & 8.177 & 39.985 \\
\hline 5 & 1.387 & 6.935 & 52.729 & 1.387 & 6.935 & 52.729 & 1.628 & 8.138 & 48.123 \\
\hline 6 & 1.223 & 6.116 & 58.844 & 1.223 & 6.116 & 58.844 & 1.620 & 8.100 & 56.223 \\
\hline 7 & 1.193 & 5.964 & 64.808 & 1.193 & 5.964 & 64.808 & 1.456 & 7.278 & 63.501 \\
\hline 8 & 1.047 & 5.236 & 70.044 & 1.047 & 5.236 & 70.044 & 1.309 & 6.543 & 70.044 \\
\hline 9 & .787 & 3.935 & 73.979 & & & & & & \\
\hline 10 & .736 & 3.680 & 77.659 & & & & & & \\
\hline 11 & .706 & 3.532 & 81.192 & & & & & & \\
\hline 12 & .644 & 3.219 & 84.411 & & & & & & \\
\hline 13 & .542 & 2.711 & 87.122 & & & & & & \\
\hline 14 & .496 & 2.481 & 89.602 & & & & & & \\
\hline 15 & .456 & 2.279 & 91.881 & & & & & & \\
\hline 16 & .396 & 1.980 & 93.861 & & & & & & \\
\hline 17 & .390 & 1.948 & 95.809 & & & & & & \\
\hline 18 & .350 & 1.748 & 97.557 & & & & & & \\
\hline 19 & .275 & 1.376 & 98.933 & & & & & & \\
\hline 20 & .213 & 1.067 & 100.000 & & & & & & \\
\hline
\end{tabular}

Extraction Method: Principal Component Analysis.

Table 3: Representation of division of 20 statements among the 8 factors derived

\begin{tabular}{|c|c|c|c|}
\hline $\begin{array}{c}\text { Factor } \\
\text { Numbers }\end{array}$ & Factors Quality & Quality Dimension & $\begin{array}{c}\text { Factor } \\
\text { Loading }\end{array}$ \\
\hline \multirow[t]{2}{*}{ FACTOR 8} & Brand Exploration & Innovative Teaching / Learning Methods & 0.817 \\
\hline & \multirow{4}{*}{ Brand Loyalty } & Institutions provide scholarships to deserving students. & 0.69 \\
\hline \multirow{3}{*}{ FACTOR 7} & & In addition to core faculty, visit of faculty IIM's executive from industry & 0.639 \\
\hline & & Qualified Faculty of the Institution & 0.622 \\
\hline & & On/Off campus Recruitment Activity carried out in the Institution & 0.237 \\
\hline \multirow{2}{*}{ FACTOR 6} & \multirow{2}{*}{ Brand Awareness } & Appealing and attractive Infrastructures of the Institution & 0.861 \\
\hline & & Innovative Course Curriculum offered by the Institution & 0.463 \\
\hline FACTOR 5 & Brand Conciseness & Facilities available in the Institutes & 0.794 \\
\hline \multirow{2}{*}{ FACTOR 4} & \multirow{2}{*}{ Brand Knowledge } & Cost of Tuition fees charged by the Institution per semester & 0.83 \\
\hline & & Amount of Capitation fees asked by the Institution during admission & 0.789 \\
\hline \multirow{3}{*}{ FACTOR 3} & \multirow{3}{*}{ Brand Mobilization } & $\begin{array}{l}\text { Courses in Soft Skills / Personality Development programs offered by } \\
\text { institution }\end{array}$ & 0.779 \\
\hline & & Institutions support services in getting Educational loans in Banks & 0.637 \\
\hline & & Past Placement records of the Institution & 0.601 \\
\hline \multirow{2}{*}{ FACTOR 2} & \multirow{2}{*}{ Brand Image } & Recommendations of friends or relatives & 0.756 \\
\hline & & Institutions Tie-ups with Abroad Universities & 0.736 \\
\hline \multirow{5}{*}{ FACTOR 1} & \multirow{5}{*}{ Brand Experience } & Institutions help for students in doing Projects in Reputed companies & 0.811 \\
\hline & & Industry Relevant Programs offered by the Institution & 0.687 \\
\hline & & Reputation of the Institution among Public. & 0.68 \\
\hline & & Intimation to parents regarding students' academic reports & 0.552 \\
\hline & & Overall Ranking \& Ratings of the Institution in various Magazine & 0.302 \\
\hline
\end{tabular}

\section{FINDING WITH MANAGERIAL APPLICATIONS}

The result of SPSS-Factor analysis can be analysis by using the 8 branding factors. The explanations of these factors are as follows:

We can rearrange these factors as per our study purpose in this sequence.

Brand Awareness: When a B-school first starts, the brand is still in the process of building consumer recognition, therefore it's more likely that customers only know a bit about it. Brand recognition will be aided by appealing and attractive infrastructures such as 24x7 Wi-Fi and innovative course curriculum given by the institution. 
Brand Knowledge: As a brand becomes more well-known, consumers learn more about its attributes and benefits. As a result, consumers no longer just know or recognize the brand, but also learn more and know a lot about it. This stage is known as brand awareness. Cost of tuition fees charged by the Institution and amount of capitation fees asked by the Institution during admission will help to make this.

Brand Exploration: With a total variance of $20 \%$, this element has emerged as the most important determinant of research. Innovative teaching / learning methods are the tools for brand exploration.

We can go for "last first and first last" class engineering approach.

Brand Conciseness: Facilities available in the Institutes like transportation facilities. Universities like Invertis have bus facilities from sahjahapur, meerganj area to college at very nominal rate which is an important factor for these areas student to select Invertis University for their MBA.

Brand Experience: Factors responsible for brand experience are Overall ranking, Projects in reputed companies, relevant programs such as career orientation programmers to enhance their own family business as well as creating new entrepreneurial culture amongst students.

Brand Loyalty: When a student get what he/she promised/perceived at the time of taking admission in the programmers' then he/she automatically become loyal to the institutes. Components of brand loyalty are Scholarships, Visit of faculties from reputed institutes, Campus Placement activities etc.

Brand Image: When people start recommending the name of institute for taking admission to their friends, relatives as well as neighbors it means institute got its image amongst the people.

Institutions tie-ups with abroad universities, foreign visits help to do this.

Brand Mobilization: Once brand image is created amongst the people institutes use the factors like past placement record, personality development programs for brand mobilization.

Past placement record helps to make strong alumina association. They help in Industry-Academia Interface, FDP, summer training and finding thrust area as well as data collection for the research.

\section{Frame work for Image Creation Model}

Research enlighten us to develop the conceptual framework of education branding, that is determining the brand equity leverage earned by the various institutions can be captured in a frame as reflected by the monitored variables of our study as an Image building model examined below:

\section{IMAGE CREATION MODEL}

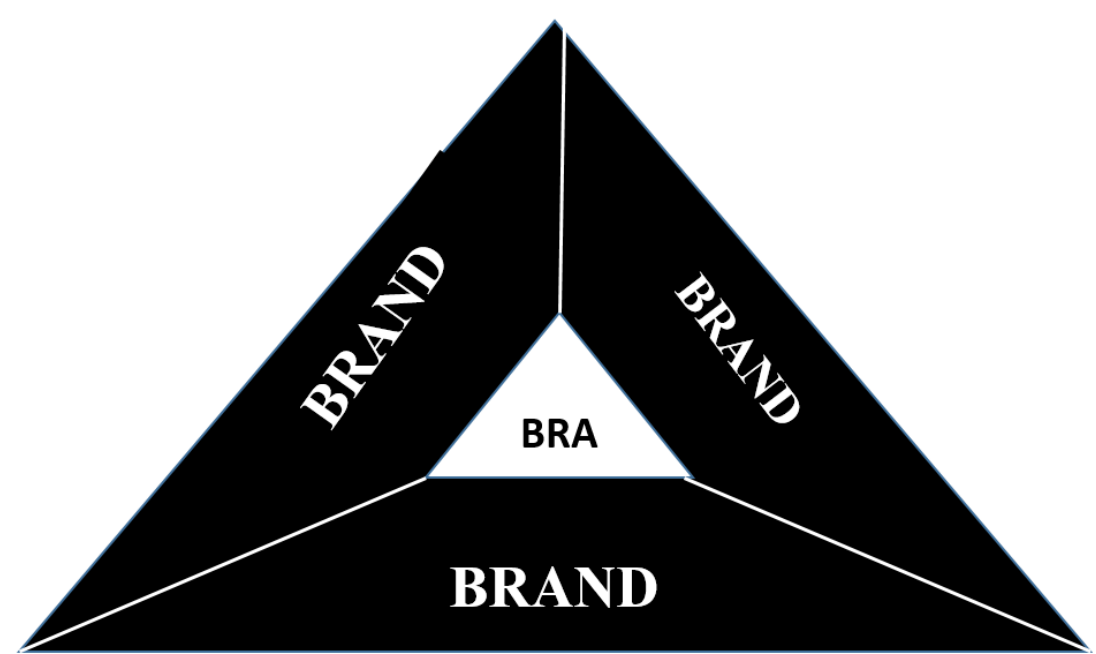

Figure 2: Proposed B-School branding model

The model throws light on the three key determinants of the brand equity, in terms of brand communication, Brand Planning and Brand Delivery.

Brand Positioning : Positioning is concerned with establishing a brand's perception in the minds of customers, as well as attaining differentiation so that it stands out from competitors' brands/offerings and fits the needs/expectations of customers. Elaborate brand image dimensions as the fundamental ingredients of the education foundations as: 
Brand Awareness: It correlated with product specification covering the core product dimensions

Brand Knowledge: Acknowledges the enrichment component associated with the product

Brand Exploration: Associates with the depth of the service quality provided by the brand

Brand Experience: The Affiliation benefits cultivated by the brand stakeholder.

Brand Delivery: Institutes must constantly monitor the impact of competition on their brands, especially in the face of intense rivalry. They should keep track of how their brands are performing in the marketplace and the impact that certain interventions will have on brand equity.

Brand Consciousness: Provider attributes and service attributes for customer satisfaction.

Brand Loyalty: Maintaining the customer satisfaction and converting it into customer delight.

Brand Communication: this articulates the creation of brand image and getting marking this image in the heart, mind and soul of the prospective by focusing on.

Brand Image: Consumers' unique experiences with the brand create new meanings and sentiments linked with the brand, which helps to strengthen the brand's image.

Brand Mobilization: Word of mouth about brand service attributes by the delight consumers.

Brand Equity: Aaker (1991a, p. 4) defines brand equity as a set of assets associated to the brand and adding value to the product or service being supplied, such as name recognition, loyal customers, perceived quality, and associations. The model's three primary components assist the B-school in achieving this goal.

More study on brand image and brand equity based on the dimensions stated in this paper, for example, by researching more indications for each dimension that have not been fully studied in this article, is recommended for further development of this idea. This can be accomplished by asking some qualitative questions on the many aspects of branding. The study of indicators from the perspective of students will enrich this notion, making it a helpful reference for future research. Furthermore, hypothesis testing research on the affects or effects on brand image might include the dimensions that exist in this study, making the research results more comprehensive for institutes to make branding strategy decisions. We also recommend that branding practitioners build a brand development strategy by referring to the brand image dimensions mentioned in this study from a brand communication perspective. This is because the research presented in this paper clearly identified several dimensions as factors that shape or reinforce brand image, making it easier for an educational brand manager or brand planner to identify strategic actions and fascinating ideas for brand image growth.

\section{REFERENCES}

Aaker, D. A., \& Stayman, D. M. (1992). Implementing the concept of transformational advertising. Psychology \& Marketing, 9(3), 237-253.

Aaker, D. A. (1991). Managing Brand Equity: Capitalizing on the Value of a Brand Name. New York: Free Press

Aaker, D. A. (2004). Leveraging the corporate brand. California management review, 46(3), 6-18.

Aaker, D. A. (2004), Brand Portfolio Strategy. Creating Relevance, Differentiation, Energy, Leverage and Clarity. New York, Free Press.

Chakrabarti, A. (2007). Higher education and research in India: An overview. Helsinki: Edita Prima.

Anderson, J. C. (2004). Business market management: Understanding, creating, and delivering value. Pearson Education India.

Annual Report: (2007-2008), Department of School Education and Literacy \& Department of Higher Education, Ministry of Human Resource Development. Government of India

Baldauf, A., Cravens, K. S., \& Binder, G. (2003). Performance consequences of brand equity management: evidence from organizations in the value chain. Journal of product \& brand management. 12 (4), 220-236.

Balmer, J. M., \& Gray, E. R. (2003). Corporate brands: what are they? What of them?. European journal of marketing. 37 (7/8), 972-997.

Balmer, J., \& Greyser, S. (2003). Revealing the corporation: Perspectives on identity, image, reputation, corporate branding and corporate level marketing. Routledge.

Bansal, S. K. (2014). Branding an academic institute: The strategic issues. Journal of International Academic Research for Multidisciplinary, 2(4), 370-376.

Bedbury, S., \& Fenichell, S. (2002). A New Brand World, Viking Penguin. New York, NY.

Bendixen, M., Bukasa, K. A., \& Abratt, R. (2004). Brand equity in the business-to-business market. Industrial marketing management, 33(5), 371-380. 
Binsardi, A., \& Ekwulugo, F. (2003). International marketing of British education: research on the students' perception and the UK market penetration. Marketing Intelligence \& Planning. Vol. 21 No. 5, pp. 318-27.

Boix, J. C., Boluda, I. K., \& López, N. V. (2020). Educational branding in private spanish universities: Building brands that the public fall in love with. Journal of Management and Business Education, 3(2), 145-163.

Chen, A. C. H. (2001). Using free association to examine the relationship between the characteristics of brand associations and brand equity. Journal of product \& brand management.

De Chernatony, L. (1999). Brand management through narrowing the gap between brand identity and brand reputation. Journal of marketing management, 15(1-3), 157-179.

Ghodeswar, B. M. (2008). Building brand identity in competitive markets: a conceptual model. Journal of product \& brand management.

Gray, B. J., Fam, K. S., \& Llanes, V. A. (2003). Branding universities in Asian markets. Journal of product \& brand management.

Hemsley-Brown, J., Melewar, T. C., Nguyen, B., \& Wilson, E. J. (2016). Exploring brand identity, meaning, image, and reputation (BIMIR) in higher education: A special section. Journal of Business Research, 69(8), 3019-3022.

Jayaraman, P., \& PRASEEDA, C. Understanding Edupreneurs-The New Breed of Entrepreneurs. International Journal of Research and Analytical, 49.

Joseph, M., Mullen, E. W., \& Spake, D. (2012). University branding: Understanding students' choice of an educational institution. Journal of Brand Management, 20(1), 1-12.

Katiyar, S. P. (2016). Gender disparity in literacy in India. Social Change, 46(1), 46-69.

Kaur, M.T.(2014) Branding higher education through zero defects approach: A Discussion. International Journal of Business Management. 1(2). pp..112-118

Kiley, K. (2010). A New Brand. Beware Higher Ed's 'Mad Men. Inside Higher Ed.

Kumar, S. R., Guruvayurappan, N., \& Banerjee, M. (2007). Cultural values and branding in an emerging market: The Indian context. The Marketing Review, 7(3), 247-272.

Lowrie, A. (2007). Branding higher education: Equivalence and difference in developing identity. Journal of Business Research, 60(9), 990-999.

Mourad, M., Ennew, C., \& Kortam, W. (2011). Brand equity in higher education. Marketing Intelligence \& Planning. 29(4), pp.403-420.

Paniker, A. S. A. M. THE ROLE OF EDUCATIONAL BRANDING IN HIGHER EDUCATION SECTOR-INDIA. Internal Quality Assurance Cell (IQAC), 107.

Panikkar, K. N., \& Nair, M. B. (Eds.). (2012). Globalization and higher education in India. Pearson Education India.

Popescu, A.I., 2012. Branding cities as educational centres. The role of higher education institutions. Management \& Marketing, 7(3), pp.493. Reports.

Retamosa, M., Millán, Á., García, J. A., \& Millán, M. (2020, April). Internal branding at university: Do tenure and job security matter?. In 6th International Conference on Higher Education Advances (HEAd'20) (No. 30-05-2020, pp. 493-500). Editorial Universitat Politècnica de València.

Schmitt, B. (2010). Experience marketing: Concepts, frameworks and consumer insights, foundations and trends in Marketing. 5(2), pp.55-112.

Wijaya, B. S. (2013). Dimensions of brand image: A conceptual review from the perspective of brand communication. European Journal of Business and Managemrnt, 5(31), 55-65.

Williams, B., Onsman, A., \& Brown, T. (2010). Exploratory factor analysis: A five-step guide for novices. Australasian journal of paramedicine, $8(3)$.

Yong, A. G., \& Pearce, S. (2013). A beginner's guide to factor analysis: Focusing on exploratory factor analysis. Tutorials in quantitative methods for psychology, 9(2), 79-94.

Publisher's note: Science Impact Publishers remain neutral with regard to jurisdictional claims in published maps and institutional affiliations.

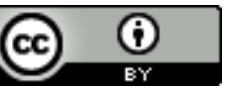

Open Access This article is licensed under a Creative Commons Attribution 4.0 International License, which permits use, sharing, adaptation, distribution and reproduction in any medium or format, as long as you give appropriate credit to the original author(s) and the source, provide a link to the Creative Commons license and indicate if changes were made. The images or other third-party material in this article are included in the article's Creative Commons license, unless indicated otherwise in a credit line to the material. If material is not included in the article's Creative Commons license and your intended use is not permitted by statutory regulation or exceeds the permitted use, you will need to obtain permission directly from the copyright holder. To view a copy of this license, visit https://creativecommons.org/licenses/by/4.0/.

(C) The Author(s) 2021 